\title{
Pengaruh Mengunyah Tebu (Saccharum Officinarum L.) dan Bengkuang (Pachyrhizus Erosus) Terhadap Perubahan Indeks Debris pada Anak Umur 8-9 Tahun di SD Adabiah Kota Padang
}

Dezy Adriantoni ${ }^{1}$, Sri Ramayanti ${ }^{1}$, Reni Nofika $^{1}$

Korespondensi : Sri Ramayantii; sriramayanti@dent.unand.ac.id; Telp: 081322213239

\begin{abstract}
Debris is food residued that found on the surface of the teeth. Accumulation of debris will trigger plaque formation, causing dental caries. Debris surface area evaluated by using the debris index. One way to reduce the debris index is to eat foods that contain water and fiber such as cane and yam, because it can help the self-cleansing and stimulate salivary flow in the mastication process. The objective of the study was to find out the effect of cane and yam chewing to change the debris index in children aged 8-9 years at Adabiah Elementary School Padang. This study used a quasi experiment method with two group pretest and posttest design that used purposive sampling with a sample of 44 students and consisted of two treatment groups. Group 1 was given the instruction to chew cane in the first day and group 2 to chew yam in the second day. The results of the study is average debris index before and after chewing a cane decreased by 0,522 and chewing a yam decreased by 0,497. Paired T-Test test results showed the value of $p=0.001(p<0.05)$ between before and after treatment in each treatment groups. The Independent $T$-Test showed that the value of $p=0.581$ ( $p>0.05$ ) between treatment groups. The Conclusion showed chewing cane and yam for children aged 8-9 years at Adabiah Elementary School Padang has an effect in decresing the debris index, but there is no significant change between both of them.
\end{abstract}

Key Words: cane, debris index, yam

Affiliasi penulis : ${ }^{1}$ Faculty of Dentistry, Universitas Andalas, Indonesia

PENDAHULUAN

Kesehatan merupakan faktor penting dalam peningkatan kualitas sumber daya manusia. Kesehatan sangat dibutuhkan oleh manusia dalam setiap kelompok usia1. Kesehatan gigi dan mulut merupakan salah satu aspek kesehatan yang harus diperhatikan dan diterapkan semenjak anak usia sekolah. Kelompok anak usia sekolah sangat rentan terhadap gangguan kesehatan gigi dan mulut, salah satu contohnya adalah karies gigi². Kesehatan gigi dan mulut perlu mendapatkan perhatian yang serius oleh pemerintah dan tenaga kesehatan di Indonesia. Hal ini disebabkan karena dilihat dari presentase penduduk yang mempunyai masalah gigi dan mulut menurut Riset Kesehatan Dasar (RISKESDAS) tahun 2013 dan 2018 meningkat dari 25,9\% menjadi 45,3\%. Berdasarkan data dari RISKESDAS 2018, masalah gigi dan mulut mencapai 58,5\% di Provinsi Sumatera Barat. Kelompok usia 5-9 tahun menunjukkan prevalensi tertinggi terhadap masalah kesehatan gigi dan mulut yaitu $54,0 \% 3$.

Permasalahan gigi pada anak usia sekolah salah satunya disebabkan karena sering mengonsumsi jenis makanan yang bersifat lengket seperti coklat, biskuit dan karamel yang dapat dengan mudah menempel pada permukaan gigi ${ }^{4}$. Sisa makanan yang menempel di permukaan gigi, diantara gigi dan gingiva disebut dengan debris ${ }^{5}$. Kebanyakan debris makanan akan mengalami liquifikasi dan bersih 
dalam 5-30 menit, namun pada debris makanan yang bersifat kariogenik dapat melekat pada gigi lebih lama kemudian menghasilkan asam yang dapat merusak gigi ${ }^{6}$. Apabila debris atau sisa makanan yang menumpuk disekitar gigi tidak dibersihkan maka kondisi ini akan memicu pembentukan plak yang lamakelamaan akan menyebabkan terjadinya proses pembentukan karies gigi?

Karies gigi merupakan suatu penyakit yang mengenai jaringan keras gigi, yang terjadi akibat proses pelarutan mineral permukaan gigi secara bertahap. Proses karies gigi terjadi karena aktivitas jasad renik dalam karbohidrat yang dapat diragikan. Proses ini ditandai dengan demineralisasi jaringan keras (enamel, dentin dan sementum) dan diikuti kerusakan materi organik gigi dengan produksi asam oleh hidrolisis dari akumulasi sisa-sisa makanan pada permukaan gigi, sehingga dapat terjadi invasi bakteri lebih jauh ke bagian dalam gigi, yaitu lapisan dentin serta dapat mencapai pulpa ${ }^{8}$. Karies gigi mengakibatkan pertumbuhan yang kurang maksimal pada anak diusia pertumbuhan, karena dapat mengalami kehilangan daya kunyah dan terganggunya proses pencernaan ${ }^{9}$.

Usia sekolah dasar merupakan saat yang ideal untuk dilakukan upaya kesehatan gigi dan mulut. Usia ini merupakan awal mulai tumbuh gigi permanen dan merupakan kelompok yang berisiko tinggi terhadap karies gigi ${ }^{10}$. Usia 8-10 tahun merupakan kelompok usia kritis terhadap terjadinya karies gigi dan mempunyai sifat khusus yaitu transisi pergantian gigi susu ke gigi permanen ${ }^{11}$. Upaya pemeliharaan kesehatan gigi dan mulut yang dilakukan sedini mungkin dapat mencegah terjadinya karies gigi. Tindakan yang dapat dilakukan untuk memelihara kebersihan gigi dan mulut adalah dengan menyikat gigi dan memakan makanan yang mengandung serat dan air, karena makanan tersebut mempunyai kemampuan sebagai pembersih alami (self-cleansing) pada gigi ${ }^{12}$.

Self-cleansing di rongga mulut dapat terjadi ketika mengunyah makanan berair dan berserat karena dapat membersihkan permukaan gigi dengan menstimulasi aliran saliva ${ }^{12}$. Pengunyahan makanan yang bertekstur keras dan kasar dapat meningkatkan pembersihan dan mengurangi retensi makanan di rongga mulut ${ }^{11}$. Makanan yang banyak mengandung air dan serat di antaranya adalah tebu (Saccharum officinarum L.) dan bengkuang (Pachyrhizus erosus). Tebu (Saccharum officinarum L.) memiliki cairan yang disebut nira dengan kandungan presentase $87,5 \%$ dan seratnya $12,5 \%$ dari bobot tebu tersebut. Cairan tebu mengandung senyawa saccharant dan vitamin B2 (riboflavin) yang berfungsi sebagai antidiabetes serta memiliki kandungan mineral yang banyak yaitu zat besi, fosfor, kalsium, kalium, zat besi dan magnesium yang baik untuk kesehatan dan memiliki salah satu manfaat dalam mengatasi kerusakan gigi. Serat yang terkandung dalam tebu mengandung selulosa, pentosan, dan lignin yang sangat berguna untuk kebersihan gigi dan mulut. Sifat mekanis dari serat tebu yang dikunyah menimbulkan efek seperti sikat yang dapat membersihkan permukaan gigi ${ }^{13}$.

Bengkuang (Pachyrhizus erosus) merupakan buah yang memiliki kandungan air dengan persentase $85,10 \%$ dan seratnya $5,49 \%$ dari bobot bengkuang tersebut. Cairan yang terkandung di dalam bengkuang seperti isoflavon dimanfaatkan sebagai antioksidan dan dapat menurunkan kadar kolesterol jahat $(\mathrm{LDL})^{14}$. Serat dalam bengkuang memiliki kandungan seperti kalsium fosfor dan vitamin $\mathrm{C}^{16}$. Bengkuang memerlukan pengunyahan yang cukup keras sehingga mampu meningkatkan sekresi saliva dan dapat membersihkan gigi dari sisa-sisa makanan secara alami ${ }^{15}$. Pengunyahan merupakan gerakan yang akan merangsang pengeluaran saliva dengan kandungan anti bakteri, senyawa glikoprotein, kalsium 
dan fluoride didalamnya. Saliva yang dihasilkan dari gerakan mengunyah dapat menghilangkan debris atau sisa-sisa makanan dan menetralisir zat-zat asam dari sisa makanan yang terdapat pada pit dan fisur permukaan gigi, namun permukaan gigi belum dapat dibersihkan secara optimal hanya dengan saliva ${ }^{2}$.

Kebersihan gigi dan mulut seseorang dapat diukur menggunakan suatu indeks. Salah satu indeks yang biasa digunakan untuk melihat luas permukaan debris yaitu indeks debris. Indeks debris adalah skor debris yang menempel pada permukaan gigi penentu. Pengukuran indeks debris ini dilakukan untuk mengukur permukaan gigi yang ditutupi oleh debris ${ }^{11}$. Pemilihan tebu dan bengkuang sebagai bahan penelitian karena mudah ditemukan, harganya murah dan rasanya yang enak sehingga disukai oleh anakanak.

\section{METODE}

Desain penelitian ini adalah penelitian quasi experiment dengan teknik two group pre-test and post-test design, yaitu suatu penelitian yang dilakukan untuk menilai dua kelompok sebelum dan sesudah diberi perlakuan tanpa menggunakan kelompok pembanding. Sampel penelitian berjumlah 22 orang pada masing-masing kelompok. Penelitian ini dilakukan di SD Adabiah Kota Padang, pada 21-25 Juni 2019. Teknik pengambilan sampel adalah dengan purposive sampling. Sampel yang memenuhi kriteria kemudian diminta untuk mengisi informed consent. Selanjutnya dilakukan pretest, perlakuan, dan posttest pada kedua kelompok. Data yang didapatkan dianalisis dengan uji paired $t$-test dan uji independent $t$-test.

\section{HASIL DAN PEMBAHASAN}

\section{Perbedaan Rata-rata Indeks Debris Anak Usia 8-9 Tahun SD Adabiah Kota Padang Sebelum dan Sesudah Mengunyah Tebu}

Rata-rata indeks debris dari 44 orang anak usia 8-9 tahun SD Adabiah Kota Padang mengalami penurunan sesudah mengunyah tebu. Penurunan dilihat dari rata-rata indeks debris sebelum dan sesudah perlakuan yaitu dari 1,163 menjadi 0,640. Hasil uji paired t-test rata-rata indeks debris kelompok mengunyah tebu pretest dan posttest menunjukkan nilai $\mathrm{p}=0,001$ yang artinya terdapat perbedaan yang bermakna pada penurunan indeks debris sebelum dan sesudah mengunyah tebu. Hal ini menunjukan bahwa mengonsumsi tebu dapat berpengaruh terhadap penurunan indeks debris, karena tebu memiliki kandungan air $87,5 \%$ dan serat sebanyak $12,5 \%$ dari bobot tebu tersebut ${ }^{13}$. Makanan padat dan berserat seperti tebu akan meningkatkan intensitas pengunyahan di dalam rongga mulut. Serat dalam tebu memiliki sifat mekanis yaitu menimbulkan efek seperti sikat dan merupakan pembersih alami sehingga memiliki kemampuan untuk menyingkirkan partikel-partikel makanan pada permukaan gigi geligi selama proses pengunyahan ${ }^{17}$. Kandungan air dalam tebu yang dikunyah memiliki fungsi sebagai pembersih alami dalam rongga mulut yang dapat menstimulasi dan meningkatkan aliran saliva. Semakin banyak produksi saliva yang dihasilkan, dapat membantu proses self-cleansing untuk membersihkan permukaan gigi dari sisa makanan ${ }^{12}$.

Hasil penelitian ini sesuai dengan hasil penelitian yang dilakukan Cahyo Nugroho pada tahun 2017 mengenai efek mengonsumsi tebu terhadap kebersihan gigi dan mulut siswa kelas $V$ SD. Penelitian 
tersebut menunjukkan bahwa adanya perubahan tingkat kebersihan gigi dan mulut sebelum dan sesudah mengunyah tebu, yaitu menambah kriteria OHI-S kategori baik dan tidak ada sampel penelitian yang berada dalam kategori buruk ${ }^{13}$.

Kandungan yang terdapat dalam batang tebu (Saccharum officinarum L.) selain serat dan air satunya adalah flavonoid ${ }^{18}$. Flavonoid memiliki daya anti bakteri sehingga dapat menghambat pertumbuhan bakteri plak pada gigi ${ }^{19}$.

\section{Perbedaan Rata-rata Indeks Debris Anak Usia 8-9 Tahun SD Adabiah Kota Padang Sebelum dan Sesudah Mengunyah Bengkuang}

Rata-rata indeks debris dari 44 orang anak usia 8-9 tahun SD Adabiah Kota Padang mengalami penurunan sesudah mengunyah bengkuang. Penurunan dilihat dari rata-rata indeks debris sebelum dan sesudah perlakuan yaitu dari 1,2682 menjadi 0,7705 . Hasil uji paired $t$-test rata-rata indeks debris kelompok mengunyah bengkuang pretest dan posttest juga menunjukkan nilai $p=0,000$ yang artinya terdapat perbedaan yang bermakna pada penurunan indek debris sebelum dan sesudah mengunyah bengkuang. Hal ini menunjukan bahwa mengonsumsi bengkuang dapat berpengaruh terhadap penurunan indeks debris, karena kandungan air yang terdapat didalam bengkuang mencapai 85,10\% dan memiliki kandungan serat sebanyak $5,49 \%$ dari bobot bengkuang ${ }^{20}$. Serat yang terkandung dalam bengkuang akan mengalami pergesekan pada proses pengunyahan sehingga mampu melepaskan sisa makanan yang melekat pada permukaan gigi dan merangsang sekresi saliva hingga terjadinya self-cleansing ${ }^{21}$. Konsistensi bengkuang yang padat memerlukan pengunyahan yang cukup keras sehingga dapat meningkatkan intensitas dan lama pengunyahan. Gerakan pengunyahan yang berulang akan membuat sekresi saliva terus bertambah karena pengunyahan dipengaruhi oleh kekerasan dari jenis makanan. Produksi saliva yang banyak dapat meningkatkan pembersihan dan mengurangi retensi makanan di rongga mulut ${ }^{2}$.

Hasil penelitian ini sesuai dengan hasil penelitian yang dilakukan Sondang pada tahun 2014 mengenai efektifitas mengunyah bengkuang terhadap penurunan debris indeks pada siswa kelas III SD Negeri 060930 Titi Kuning Medan. Penelitian tersebut ditunjukkan bahwa mengunyah bengkuang dapat menurunkan indeks debris ${ }^{15}$.

Kandungan yang terdapat dalam bengkuang (Pachyrhizus erosus) selain air dan serat adalah isoflavon. Cairan isoflavon dalam bengkuang ini dapat menghambat aktifitas enzim glucosyltransferase yang merupakan hasil produk yang dihasilkan oleh streptococcus mutans yang terlibat dalam proses terjadinya karies gigi22.

\section{Perbedaan Rata-rata Indeks Debris Anak Usia 8-9 Tahun SD Adabiah Kota Padang Sebelum dan Sesudah Mengunyah Tebu dan Bengkuang}

Hasil uji independent $t$-test menunjukan perbedaan yang tidak bermakna pada selisih rata-rata penurunan indeks debris sesudah mengunyah tebu dan bengkuang karena didapatkan nilai $p>0,05$. Kelompok yang mengunyah tebu dan bengkuang secara statistik memiliki pengaruh yang sama dalam menurunkan indeks debris sampel penelitian. Hal tersebut dikarenakan tebu dan bengkuang memiliki 
beberapa kesamaan yang dapat membantu menghilangkan debris yang menempel pada permukaan gigi. Persamaan tersebut adalah sama-sama mempunyai kandungan serat dan air yang banyak. Tebu memiliki kandungan serat sebanyak $12,5 \%$ dan air $87,5 \%$ sedangkan bengkuang memiliki kandungan serat sebanyak $5,49 \%$ dan air $85,7 \%$. Kedua makanan ini memiliki konsistensi yang keras, padat dan kasar sehingga memerlukan gerakan pengunyahan yang sering sehingga meningkatkan sekresi saliva². Sekresi saliva merupakan hasil dari adanya stimulus mekanis dan kimiawi yang terjadi di dalam rongga mulut ${ }^{23}$.

Pengunyahan merupakan proses mekanis yang melibatkan organ di dalam rongga mulut seperti lidah, gigi-geligi dan otot pengunyahan. Proses ini akan merangsang produksi saliva yang dapat menghilangkan sisa-sisa makanan di rongga mulut. Produksi saliva juga dipengaruhi oleh jenis makanan yang dikunyah. Secara fisiologis makanan padat dan berserat akan meningkatkan produksi saliva ${ }^{24}$. Serat dalam makanan berguna sebagai daya pembersih gigi yang baik karena serta mengandung air yang banyak sehingga mengunyah makanan yang berserat dan berair dapat merangsang gingiva meningkatkan sekresi saliva di dalam mulut dan mencegah penumpukan sisa makanan yang akan menimbulkan plak pada permukaan gigi ${ }^{25}$. Pada proses pengunyahan tebu dan bengkuang, partikel-partikel makanan yang menempel pada permukaan gigi dapat terlepas akibat terjadinya pergesekan antara serat-serat yang terkandung dalam makanan tersebut ${ }^{11}$.

Makanan berserat dan berair seperti tebu dan bengkuang ini memiliki rasa yang dapat menstimulasi sekresi saliva dengan melibatkan proses kimiawi yang terjadi didalam rongga mulut. Stimulus kimiawi ini dapat muncul akibat adanya efek kesan pengecapan dari makanan yg dikonsumsi²3.

\section{SIMPULAN}

Mengunyah tebu dan bengkuang yang dilakukan pada anak usia 8-9 tahun di SD Adabiah Kota Padang, memperoleh kesimpulan sebagai berikut:

1. Penelitian ini menunjukkan pengunyahan tebu dan bengkuang pada anak usia 8-9 tahun di SD Adabiah Kota Padang memiliki pengaruh dalam menurunkan indeks debris, namun tidak terdapat perbedaan yang bermakna antara keduanya.

2. Selisih rata-rata indeks debris sebelum dan sesudah mengunyah tebu mengalami penurunan yang bermakna yaitu sebesar 0,522 dengan nilai $p=0,001$, sehingga mengunyah tebu dapat berpengaruh terhadap penurukan indeks debris seseorang.

3. Selisih rata-rata indeks debris sebelum dan sesudah mengunyah bengkuang mengalami penurunan yang bermakna yaitu sebesar 0,497 dengan nilai $p=0,001$, sehingga mengunyah bengkuang dapat berpengaruh terhadap penurunan indeks debris seseorang.

\section{KEPUSTAKAAN}

1. Salih, H.S., Assessment Knowledge of Primary School Teachers Regarding to the Prevention of Dental Caries in Kirkuk City. Journal of Health, Medicine and Nursing. 2016; 28: 97-103.

2. Haida, K. E., Cholil, Aspriyanto, D., Perbandingan Efektivitas Mengunyah Buah Pir dan Bengkuang Terhadap Penurunan Indeks Plak Tinjauan Pada Siswa SDN Gambut 9 Kabupaten Banjar. Jurnal Kedokteran Gigi (Dentino), 2014, pp. 24-28. 
Fakultas Kedokteran Gigi Universitas Andalas

Jalan Perintis Kemerdekaan No. 77 Padang, Sumatera Barat

Web: adj.fkg.unand.ac.id Email: adj@dent.unand.ac.id

3. Departemen Kesehatan RI, Laporan Hasil Riset Kesehatan Dasar (RISKESDAS) Nasional. Badan Penelitian dan Pengembangan Kesehatan Dasar Depkes RI. Jakarta. 2013.

4. Seajima, O. I., et al., Pengaruh Konsumsi Apel (Pyrus malus) Terhadap Indeks Debris Pada Anak Usia 9 Tahun Di SD Katolik St. Theresia Malalayang. Jurnal e-GiGi (eG). 2015; 3(2): 403-408.

5. Cahyati, Konsumsi Buah Pepaya Dalam Menurunkan Debris Indeks. Jurnal Kesehatan Masyarakat, 2013; 8(2): 127-136.

6. Listrianah, Hubungan Menyikat Gigi Dengan Pasta Gigi Yang Mengandung Herbal Terhadap Penurunan Skor Debris Pada Pasien Klinik Gigi An-Nisa Palembang. JPP (Jurnal Kesehatan Palembang). 2017; 12(1): 83-94.

7. Malohing, Anindita, Gunawan, Status Karies pada Gigi Berjejal di SD 12 Tuminting. Jurnal e-GiGi (eG). 2013; 1(2): 94-98.

8. Yundali, S.H., Adityaarman, M., Kesehatan Gigi dan Mulut. Bandung: Pustaka Reka Cipta. 2012.

9. Widayati, N., Faktor yang Berhubungan dengan Karies Gigi pada Anak Usia 4-6 Tahun. Jurnal Berkala Epidemiologi. 2014; 2(2): 196-205.

10. Setiari., Lidia, S., Sulistyowati, M., Tindakan Pencegahan Karies Gigi pada Siswa Sekolah Dasar Berdasarkan Teori Health Belief Model. Jurnal Promkes. 2017; 5(1): 59-70.

11. Lusnarnera., et al., Pengaruh Konsumsi Semangka (Citrullus Lanatus) Dalam Menurunkan Indeks Debris pada Anak Usia 8-10 Tahun. Jurnal e-GiGi (eG), 2016; 4(1): 53-58.

12. Prasetyowati., Silvia., Nuratni, N. K., Pengaruh Mengunyah Buah Jambu Biji terhadap Perubahan Debris Index pada Siswa Kelas III dan IV di MI Baiturahman Surabaya. Jurnal Kesehatan Gigi. 2014; 2(2): 242-247.

13. Nugroho, C., Efek konsumsi Jajanan Tebu Batang terhadap Kebersihan Gigi dan Mulut pada Siswa-siswi Kelas V SDN 3 Palimanan Timur Kecamatan Palimanan Kabupaten Cirebon. Indonesian Oral Health Journal. 2017; 2(1): 1-8.

14. Nurasiki dan Amiruddin. Efektivitas Mengunyah Buah Apel dan Buah Bengkoang Terhadap Penurunan Indeks Plak Pada Murid Sekolah Dasar. Jurnal AcTion: Aceh Nutrition Journal. 2017; 2 (2): 80-85.

15. Sondang, Efektifitas Men gunyah Buah Bengkuang Terhadap Penurunan Debris Indeks Pada Siswa Kelas III A SD Negeri 060930 Titi Kuning. Jurnal IImiah PANNMED. 2014; 8(3): 326-329.

16. Apriadji, W.H., 180 Jus Buah dan Sayuran. Jakarta: PT. Gramedia Pustaka Utama. 2006.

17. Aljufri, Sriani, Y., Perbedaan Indeks Debris Mahasiswa Mengunyah Buah Apel, Nanas dan Belimbing di JKG Poltekes Kemenkes Padang. Jurnal Kesehatan Masyarakat (JKMA), 2017; 12(1), 16-22.

18. Nasir, S., Doni, M., Andonie, R., Pengaruh Kondisi Operasi Pada Pembuatan Asap Cair Dari Ampas Tebu Dan Serbuk Gergaji Kayu Kulim. Jurnal Teknologi Teknik Kimia. 2008; 4(15): 8-15.

19. Priyanto A, Islamiyati R. Uji Aktivitas Antioksidan pada Batang Tebu Hijau dan Batang Tebu Merah Menggunakan Metode Perendaman Radikal Bebas DPPH. Cendekia Journal of Pharmacy 2018; 2 (1): 50-59. 
20. Tumembow SO dan Wowor VNS. Pengaruh Konsumsi Buah Pepaya California dan Pepaya Hawai Terhadap Penurunan Indeks Debris Anak. E-Gigi 2018; 6 (2).

21. Nurasiki dan Amiruddin. Efektivitas Mengunyah Buah Apel dan Buah Bengkoang Terhadap Penurunan Indeks Plak Pada Murid Sekolah Dasar. Jurnal AcTion: Aceh Nutrition Journal. 2017; 2 (2): 80-85.

22. Devulapalle, K. S., Mooser, G., Glucosyltransferase Inactivation Reduces Dental Caries. Journal of Dental Research, 2001; 80(2): 466-9.

23. Indriana, Perbedaan Laju Saliva dan pH karena Pengaruh Stimulus Kimiawi dan Mekanis. J Kedokt Meditek. 2011; 17(44): 1-5.

24. Lusiani, S., Herlinawati., Aminah, B.S., Efektivitas Mengkonsumsi Tebu dan Jambu Biji Terhadap Penurunan Indeks Plak Pada Siswa/i SMP Negeri 31 Kodyamedan Kecamatan Medan Tuntungan. Jurnal IImiah PANNAMED. 2017; 12(2): 204-208.

25. Nugroho C. Efek Konsumsi Jajanan Tebu Batang Terhadap Kebersihan Gigi dan Mulut Pada Siswa Siswi Kelas V SDN 3 Palimanan Timur Kecamatan Palimanan Kabupaten Cirebon. Indonesian Oral Health Journal 2017; 2 (1): 1-8. 